\title{
Уровень сформированности школьных навыков и эмоционально-волевые качества у детей с малой мозговой дисфункцией
}

Серов П.Н.

В данной статье рассматривается вопрос о возрастных изменениях школьных навыков и эмочионально-волевой сферы мальчиков 7-16-летнего возраста. Предположительно, трудности в обучении у обследованных детей сохраняются с возрастом из-за нарушения регуляторных механизмов мозга, приводящих к развитию гиперактивности.

Ключевые слова: малая мозговая дисфункция, школьные навыки.

Малая мозговая дисфункция (ММД) - это слабо выраженная форма детской энцефалопатии [7]. Число детей, страдающих ММД, в общей детской популяции по данным разных авторов колеблется от 2 до 21 \%. Признаки ММД крайне разнообразны и меняются с возрастом. Основные признаки наиболее ярко проявляются в первые годы обучения в виде повышенной моторной активности и отвлекаемости (синдром гиперактивности с дефицитом внимания). Такие дети длительное время не могут сосредоточиться на чем-нибудь одном, все время отвлекаются на различные раздражители [1]. В первых классах школы у некоторых детей возникают трудности в обучении, которые не связаны с умственным дефектом или нарушениями поведения. Может быть нарушено восприятие пространственных взаимоотношений, нарушены счет и чтение. С возрастом появляются и нарастают трудности в абстрактном мышлении. Особенно частыми бывают речевые нарушения. [2]. При относительной «мягкости» неврологической симптоматики большой процент этих детей попадает в группу риска, в группу детей, отстающих или неспособных к усвоению школьных знаний и навыков [4]. «Неблагополучное» созревание ЦНС становится препятствием для своевременного и полноценного формирования психической деятельности у этих детей. Психические возможности ребенка оказываются недостаточными, чтобы соответствовать социальным требованиям, которые предъявляют родители, детский сад, школа [5]. Несмотря на значительный прогресс в изучении проблемы социальной адаптации детей с отклонениями в развитии ЦНС, многие аспекты этой важной медико-психологической проблемы еще не разрешены [3].

Целью данного исследования было изучение показателей школьных навыков у мальчиков 7-16-летнего возраста с малой мозговой дисфункцией.

Проведенное исследование явилось сравнительным, рандомизированным, открытым, групповым. Основную группу составили 86 мальчиков 7-16-летнего возраста с малой мозговой дисфункцией (ММД). Школьники с ММД были разделены на группы по возрастному критерию по классификации ВОЗ (1997): младший школьный возраст, ранняя фаза пубертатного периода и средняя фаза пубертатного 
периода. Диагностику школьных трудностей, нарушений эмоционально-волевой сферы проводили с использованием стандартного набора тестов [6].

Согласно результатам тестирования детей с ММД младшего школьного возраста, 36 \% школьников испытывают трудности поведения, а у $64 \%$ детей данных трудностей нет. При этом значительные трудности в обучении испытывают 53,5 \% детей младшего школьного возраста, т.е. у них обнаружены трудности в чтении, письме, а также счете. Часто дети просто не способны выявить разницу между числами в пределах одного десятка. При этом у этих детей наблюдали сочетание незрелости интеллектуальной и эмоциональной сфер. Так, при исследовании особенностей эмоционально-волевой сферы и функции внимания было показано, что нервозность и тревожность часто проявляются у $29 \%$, редко -у 35,5\%, очень редко - у 35,5 \% мальчиков. Двигательное беспокойство и расторможенность очень часто проявляется у $25 \%$, редко - у $43 \%$, очень редко - у $32 \%$ мальчиков. Рассеянность, отвлекаемость очень часто проявляется у $21,5 \%$, часто - у $25 \%$, редко - у $32 \%$, очень редко - у 21,5 \% мальчиков. Признаки утомляемости и истощаемости ЦНС часто проявляются у $64,5 \%$, редко - у $14 \%$, очень редко - у $21,5 \%$ мальчиков. Вялость и пассивность при выполнении задания часто проявляются у $46,4 \%$, редко - у $21,5 \%$, очень редко - у 32,1 \% мальчиков. Робость, скованность часто выявляются у $71,4 \%$, редко - у $14,3 \%$, очень редко - у $14,3 \%$ мальчиков.

В ранней фазе пубертатного периода у детей с ММД менее высокий процент школьников страдал нарушением поведения (17,8 \%). Однако, в эмоциональноволевой сфере этих детей также обнаружены признаки нервозности, гиперактивности, повышенной тревожности и т.д. В том числе, признаки нервозности и тревожности часто выявлялись у $17,8 \%$, редко - у $53,5 \%$, очень редко - у $28,7 \%$ мальчиков. Двигательное беспокойство и расторможенность часто проявлялись у $10,7 \%$, редко - у $32 \%$, очень редко - у $28,65 \%$ мальчиков. Рассеянность, отвлекаемость часто выявлялась у $14,2 \%$, редко - у $28,6 \%$, очень редко - у $35,7 \%$ школьников. Признаки утомляемости и истощаемости ЦНС часто проявлялись у $39 \%$, редко - у 21,5 \%, очень редко - у 28,6 \% детей. Признаки пассивности и вялости при выполнении предъявляемого задания часто проявляются у $32,15 \%$, редко - у $35,7 \%$, очень редко - у 32,15 \% мальчиков. Робость и скованность у детей ранней фазы пубертатного периода часто выявлялись в 17,8 \%, редко - в $14 \%$ случаев.

К средней фазе пубертатного периода у подростков с ММД вновь обнаруживается возрастание процента школьников с нарушением поведения (56,7 \%) и эмоционально-волевой сферы. Признаки нервозности и тревожности часто проявляются у 40 \% подростков, у остальных мальчиков - редко. Признаки гиперактивности у подростков этой группы наблюдали примерно с той же частотой, что и в ранней фазе пубертатного периода: двигательное беспокойство и расторможенность часто проявляются у $10 \%$, редко - у 33,3 \% школьников, у 56,7 \% подростков эти признаки не проявляются. Рассеянность, отвлекаемость часто проявляется у $16,7 \%$, редко - у $40 \%$, очень редко - у 43,3 \% школьников. Признаки утомляемости и истощаемости ЦНС часто проявляются у $46,7 \%$, редко - у $26,65 \%$, 
очень редко - у 26,65 \%. Раздражительность и агрессивность часто проявляется у 6,7 \% подростков. Признаки пассивности и вялости при выполнении задания часто проявляются у 26,6 \%, редко - у 73,4 \% школьников. Робость и скованность у этих подростков редко проявляется лишь в 10 \% случаев, у остальных эти признаки не выражены.

Таким образом, при ММД снижение поведенческих и эмоционально-волевых нарушений происходит к ранней фазе пубертатного периода, но к 13-16 годам, вновь, отмечается возрастание этих отклонений. У мальчиков 11-16 лет сохраняются и нарушения школьных навыков. В то же время, признаки гиперактивности в ранней и средней фазах пубертатного периода проявляются более выражено относительно младшего школьного возраста. Следовательно, нарушение регуляции деятельности мозга, поведенчески проявляющееся синдромом гиперактивности, повышается при ММД с возрастом.

\section{Литература}

1. Безруких М.М., Мачинская Е.В., Крупская Е.В., Семенова О.А. Психофизиологическая диагностика и психолого-педагогическая помощь детям с СДВГ. / В кн.: Альманах «Новые исследования». - М.: Вердана, 2006. - № 2 (10). - С. 9-35.

2. Богданова Т.Г., Корнилова Т.В. Диагностика познавательной деятельности. - М.: Роспедагентство, 1994. - 68 с.

3. Вольф Н.В., Гребнева О.Л., Джафаров О.А. и др. Проблемы, рекомендации и перспективы при изучении синдрома дефицита внимания с гиперактивностью / Альманах «Новые исследования». - М.: Вердана, 2006. - № 2 (10). - С. 36-56.

4. Заваденко Н.Н. Как понять ребенка: дети с гиперактивностью и дефицитом внимания. - М.: Издательский дом «Школа-Пресс 1», 2001. - 128 с.

5. Лебединский В.С., Никольская О.С. Эмоциональные нарушения в детском возрасте и их коррекция. - М.: Медицина, 1990. - 190 с.

6. Семаго Н.Я., Семаго М.М. Проблемные дети: основы диагностики и коррекционной работы психолога. - М.: АРКТИ, 2000. - 232 с.

7. Яременко Б.Р., Яременко А.Б., Горяинова Т.Б. Минимальные дисфункции головного мозга. - Санкт-Петербург, 2002. - 128 с. 